\section{Dissolution test of herbal medicines containing Passiflora sp.}

\author{
Ane R. T. Costa, Suzana F. Alves, Edemilson C. da Conceição, \\ Clévia F. D. Garrote, José R. Paula, Maria Teresa F. Bara*
}

Laboratório de Pesquisa em Produtos Naturais, Faculdade de Farmácia, Universidade Federal de Goiás, Brazil.
Revista Brasileira de Farmacognosia Brazilian Journal of Pharmacognosy 21(3): 525-531, May./Jun. 2011

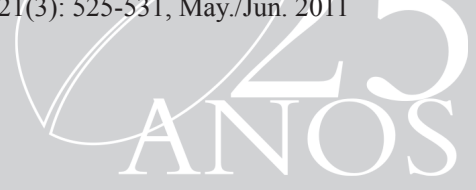

\begin{abstract}
The dissolution test is an essential tool to assess the quality of herbal medicines in the solid dosage form for oral use. This work aimed to evaluate the dissolution behavior of three herbal medicines in the form of capsules and tablet containing Passiflora, produced with powder or dried extract. Assay of total flavonoids and dissolution methods were validated and obtained results allowed the quantification of flavonoids with precision, accuracy and selectivity. The percentage of total flavonoids found was $2 \%$ for capsule A (containing only powder), $0.97 \%$ for capsule B (containing only dried extract) and 5.5\% for tablet. Although the content was lower, the release of flavonoids present in the capsule containing dried extract was $12 \%$ higher over $30 \mathrm{~min}$, with dissolved percentage values of 87 and 75 , for the capsules containing extract and powder, respectively. The tablet containing dried extract presented dissolution of $76 \%$, despite the higher content of flavonoids, which may be due to pharmacotechnical problems. Obtained data demonstrated the need to implement these tests in the quality control of herbal medicines, confirming the release of the active ingredients that underlie the pharmacological action of these medicines.
\end{abstract}

\section{Article}

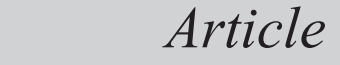

Received 10 Apr 2010 Accepted 22 Sep 2010 Available online 20 May 2011

Keywords: flavonoids natural product Passiflora passion fruit quality control

ISSN $0102-695 \mathrm{X}$ doi: $10.1590 / \mathrm{S} 0102-695 \mathrm{X} 2011005000083$

\section{Introduction}

Herbal products are medicines whose active principles are exclusively derived from vegetable drugs. They are characterized by knowledge of the effectiveness and risks of their use, as well as by the reproducibility and constancy of their quality (WHO, 1996; Emea, 2003). Although they are natural products, they are not necessarily innocuous (Bateman et al., 1998; Turolla \& Nascimento, 2006).

Dissolution studies represent an indispensable tool for pharmaceutical development, since they make it possible to check whether the formulation is suitable for the purpose for which it is intended (Sittichai et al., 2007). In the sector of pharmaceutical production and quality control, the dissolution test can be used to detect quality deviations in parameters such as content uniformityand ensure reproducibility between production batches (Marques, 2002; Souza et al., 2007).

In order to have a therapeutic effect, it is necessary for the oral dosage form to dissolve in the appropriate section of the digestive system. After that, its active principles can be absorbed thus reaching the circulation and gaining access to sites of action. Therefore, the evaluation of the dissolution profile reveals the portion of the herbal product that is actually available for absorption in the gastrointestinal tract and that will reach the circulation. In terms of pharmacokinetics, absorption of a drug is controlled by its dissolution, so that different dissolution profiles indicate different bioavailabilities, which can lead to variations in the therapeutic and toxic effect of the product used (Ngo, 2007).

There have been few published studies on the dissolution of herbal products, and the data reported are worrying in terms of variations in the release of active principles, associated with the processing of raw material, particle size of dried extracts, moisture, and compression force, among other factors (Bempong \& Houghton, 1992; Taglioli et al., 2001; Kressmann et al., 2002; Westerhoff, et al., 2002; Kratz et al., 2008).

Given the above, the dissolution test of capsules and tablet based on Passiflora sp. is important due to it being widely consumed by the population and also because of the lack of this kind of study involving herbal medicines. In this work, methods for the quantification and release of total flavonoids were developed and validated to evaluate the dissolution behavior of capsules and tablet containing powder or dried extract of Passiflora.

\section{Materials and Methods}

Chemicals

Boric acid from Vetec (Brazil), ethyl acetate P.A. 
from CRQ (Brazil), ethanol 95\% from F. Maia (Brazil), formic acid anhydrous 99\% from Acros Organics (USA), glacial acetic acid P.A. from F. Maia (Brazil), glacial acetic acid P.A. from CRQ (Brazil), hydrochloric acid $37 \%$ from F. Maia (Brazil), isovitexin 98\% from Fluka (Germany), methanol P.A. from F. Maia (Brazil), natural products (NP): 2-aminoethanol diphenylborate from Sigma (Germany), oxalic acid P.A. from Vetec (Brazil), potassium phosphate monobasic anhydrous P.A. from Synth (Brazil), rutin 95\% HPLC grade from Sigma (Brazil), sodium hydroxide P.A. from Biotec (Brazil), and vitexin 96\% from Fluka (Germany).

\section{Samples}

Passiflora powder and dried extract were used as raw materials for the production of capsules. The tablet was randomly purchased in a local market. Dissolution tests were carried out on capsules containing $400 \mathrm{mg}$ of Passiflora sp. powder (capsule A), capsules containing $250 \mathrm{mg}$ of dried extract of Passiflora sp. (capsule B) and tablets containing $320 \mathrm{mg}$ of dried extract of Passiflora incarnata $\mathrm{L}$.

\section{Identification of flavonoids}

Flavonoids present in the raw materials, dried extract and tablet were identified by absorption spectra and by thin layer chromatography (TLC) (Wagner \& Bladt, 2001). These flavonoids were compared with reference substances vitexin, isovitexin and rutin. For TLC, $1 \mathrm{~g}$ of sample was weighed and dissolved in 10 $\mathrm{mL}$ of methanol followed by heating in a water bath for $5 \mathrm{~min}$. This solution was filtered and $30 \mu \mathrm{L}$ were applied to silica gel $60 \mathrm{~F}_{254}$ Chromatoplates Alugram (Germany), 4 x $10 \mathrm{~cm}$ in size and with a thickness of $0.25 \mathrm{~cm}$. The reference solutions used were rutin, vitexin and isovitexin, which were solubilized $(2 \mathrm{mg})$ in $10 \mathrm{~mL}$ of methanol and then $10 \mu \mathrm{L}$ were applied to the silica plates. The mobile phase used was ethyl acetate:formic acid anhydrous:glacial acetic acid:water (100:11:11:26). After the chromatographic run, the chromatogram was developed with a solution of $1 \%$ natural products (NP) in methanol, followed by visualization under UV illumination at $365 \mathrm{~nm}$.

\section{Quantitative analysis}

The moisture content was determined in raw material (powder and dried extract), the average weight of the capsules was measured, and total flavonoids were quantified in the herbal product and in the dissolution medium containing the herbal product (adapted from the British Pharmacopoeia, 2007). A Varian spectrophotometer, model Cary 50, and a Vankel dissolutor model VK 7000, were used.

Quantification of total flavonoids by UV
spectrophotometry (adapted from the British
Pharmacopoeia, 2007)

The steps taken to quantify the total flavonoids content of Passiflora in raw materials, capsules and tablet, as well as the dissolution medium, are presented in the form of a flowchart in Figure 1. The analysis of total flavonoids content was performed in triplicate. To determine the percentage of total flavonoids ( $\mathrm{TF} \%)$ in the samples a calibration curve was prepared using rutin as the standard $(0.05 \mathrm{mg} / \mathrm{mL})$ prepared in ethanol $60 \%$ $\mathrm{v} / \mathrm{v}$, followed by serial dilution to achieve concentrations ranging from $0.002 \mathrm{mg} / \mathrm{mL}$ to $0.012 \mathrm{mg} / \mathrm{mL}$. The same procedure shown in Figure 1 was then performed with the standard.

The total flavonoids content was calculated using the following formula:

$$
\mathrm{TF} \%=\mathrm{x}(\mathrm{mg} / \mathrm{mL}) \times \mathrm{DF} \times 100 / \mathrm{w}
$$

in which: $\mathrm{TF} \%=$ percentage of total flavonoids in the sample; $\mathrm{x}=$ concentration of sample according to the calibration curve in $\mathrm{mg} / \mathrm{mL}$; $\mathrm{DF}=$ dilution factor; $\mathrm{w}=$ sample weight in $\mathrm{mg}$.

To analyze the total flavonoids content in capsules and tablet all the steps shown in Figure 1 were carried out, but in the preparation of the samples initially the average weight of capsules and tablets was determined, and for the quantification of flavonoids the equivalent of $200 \mathrm{mg}$ of herbal product were weighed.

To analyze the total flavonoids content in the dissolution medium, aliquots of $50 \mathrm{~mL}$ were manually collected from each tank of the dissolutor and filtered, evaporated to complete dryness and then treated according to the procedure shown in Figure 1 (test solution). The percentage of total flavonoids in the dissolution medium (MF\%) was calculated as described for calculation of total flavonoids (TF\%), adjusting the dilution factor by 500 . To calculate the percentage of total dissolved flavonoids (Q), we used the following relationship:

$$
\begin{aligned}
\mathrm{TF} \% & ---- \\
\mathrm{MF} \% & -----\mathrm{Q}
\end{aligned}
$$

in which $\mathrm{Q}$ is the amount of total flavonoids dissolved in relation to the total flavonoid content of herbal products; $\mathrm{MF} \%=$ percentage of total flavonoids in the dissolution medium; $\mathrm{TF} \%=$ percentage of total flavonoids in the herbal products analyzed.

\section{Validation of spectrophotometry method}


The method of analysis of total flavonoids content in the capsules was validated according to Anvisa (2003). Evaluated parameters were selectivity, linearity and range, precision (repeatability and intermediate), accuracy and robustness.

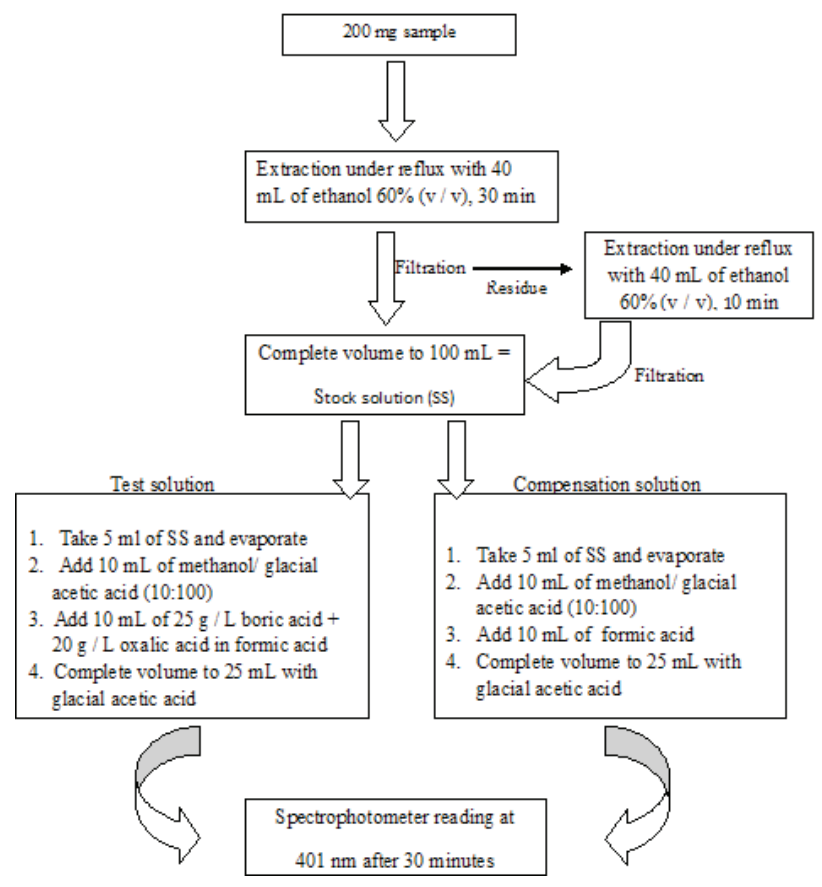

Figure 1. Method of analysis of the total flavonoids content (adapted from the British Pharmacopoeia, 2007).

The selectivity was evaluated from the analysis of the absorption spectra of solutions used in the assay, with the wavelength ranging from 200 to $800 \mathrm{~nm}$. The linearity was evaluated by processing the data by linear regression of three calibration curves using rutin as a reference substance at concentrations of 2, 4, 6, 8, 10 and $12 \mu \mathrm{g} / \mathrm{mL}$. Precision (repeatability) was determined by analyzing six replicates of the sample at the concentration of $100 \%$ (weight of $200 \mathrm{mg}$ of sample according to the pharmacopoeic method of quantification). Samples were prepared according to Figure 1 and the results were expressed as relative standard deviation (RSD\%). Precision (intermediate) was determined on two days and by two different analysts, in triplicate, at a concentration of $100 \%$. To this end, samples were prepared according to Figure 1, and the results were expressed as relative standard deviation (RSD\%). The accuracy was determined by analyzing the sample in triplicate at concentrations of $50 \%, 100 \%$ and $150 \%$ of the theoretical concentration analyzed and verified through recovery test. The robustness of the method was evaluated in triplicate by varying the wavelength of the reading (398 nm, $401 \mathrm{~nm}$ and $404 \mathrm{~nm}$ ), the spectrophotometer (equipment) and glacial acetic acid manufacturer. It was expressed as relative standard deviation $(\mathrm{RSD} \%)$.

\section{Validation of dissolution method}

The dissolution test was classified according to its purpose in test category III, hence the need for assessment of the parameter precision, by means of repeatability (Anvisa, 2003). The precision was determined by analysis of six individual samples (six replicates) collected from the dissolutor after $30 \mathrm{~min}$. The repeatability was expressed as the relative standard deviation between samples (RSD\%).

\section{Dissolution test}

The analytical methodology used to evaluate the dissolution followed the USP 30 (2007) guidelines, which describe the general methodology for a dissolution test for tablets and capsules. The test was carried out using 0.1 $\mathrm{M} \mathrm{HCl}$ as the dissolution medium, a volume of $500 \mathrm{~mL}$, apparatus 2 (paddle), with a stirring speed of $50 \mathrm{rpm}$, and at a temperature of $37 \pm 0.5{ }^{\circ} \mathrm{C}$. Aliquots of $50 \mathrm{~mL}$ were collected manually at $0,10,20$ and $30 \mathrm{~min}$, filtered and assayed by spectrophotometry at $401 \mathrm{~nm}$ after oxalo-boric acid reaction for the assay of total flavonoids, using the equation:

$$
\mathrm{Q}=\mathrm{MF} \% \times 100 / \mathrm{TF} \%
$$

in which $\mathrm{Q}$ is the amount of total flavonoids dissolved related to the total flavonoids in the herbal products assay; $\mathrm{MF} \%$ is the percentage of total flavonoids in the dissolution medium; $\mathrm{TF} \%$ is the percentage of total flavonoids in the herbal products analyzed.

\section{Results and Discussion}

\section{Sample identification}

The analysis of the absorption spectra carried out to identify the samples showed absorption peaks in the ultraviolet (UV) region characteristic of flavonoids. Scans performed on methanolic solutions of raw materials showed a peak between $269 \mathrm{~nm}$ and $300 \mathrm{~nm}$ for powder and a peak at $274 \mathrm{~nm}$ for dried extract of Passiflora, and a lower absorbance for both powder and extract in the region between 300 and $400 \mathrm{~nm}$ (Figure 2). Because of their chemical structure, flavonoids possess characteristic absorption spectra in the UV region, determined by the benzopyrone core and with two peaks of absorption, one occurring between 240 and $285 \mathrm{~nm}$ (band II) and another between 300 and $400 \mathrm{~nm}$ (band I) (Zuanazzi \& Montanha, 2007).

It should be emphasized that the choice of rutin as a marker in this study was based on its absorption spectrum in the UV region being similar to those of 
vitexin and isovitexin, which are the main markers of Passiflora. Reference substances vitexin and rutin showed two absorption peaks in the UV region characteristic of flavonoids. Furthermore, after the complexation reaction (flavonoid-reactive) spectra of test solutions prepared with rutin or vitexin and the samples showed peaks of absorption around $401 \mathrm{~nm}$. As the method used was spectrophotometry and not chromatography, this caused no inconvenience in relation to selectivity, besides which the cost of rutin makes it more accessible. A study performed by Taglioli et al. (2001) used another flavonoid, hyperoside, as a marker of Passiflora sp. in dissolution tests, and this was also quantified by spectrophotometry.

The chromatograms obtained by TLC for raw materials, herbal products and reference substances were important to support their identification and showed the presence of three easily visible spots for Passiflora dried extract with retention factors $\left(\mathrm{R}_{\mathrm{f}}\right)$ of $0.25 ; 0.56$ and 0.69 . Passiflora powder exhibited five spots with $\mathrm{R}_{\mathrm{f}}$ of 0.31 ; $0.37 ; 0.5 ; 0.62$ and 0.69 . The reference substances used, vitexin, isovitexin and rutin, showed yellow-greenish spots with $\mathrm{R}_{\mathrm{f}}$ of $0.81 ; 0.69$ and 0.5 , respectively, when visualized with natural products (NP) (Figure 3). The tablet presented seven spots with $\mathrm{R}_{\mathrm{f}}$ of $0.19 ; 0.25 ; 0.31$; $0.56 ; 0.62 ; 0.69 ; 0.75$. The chromatographic profile of these products showed the presence of flavonoids and was similar to the TLC chromatographic profile described in the British Pharmacopoeia (2007) for Passiflora incarnata species.

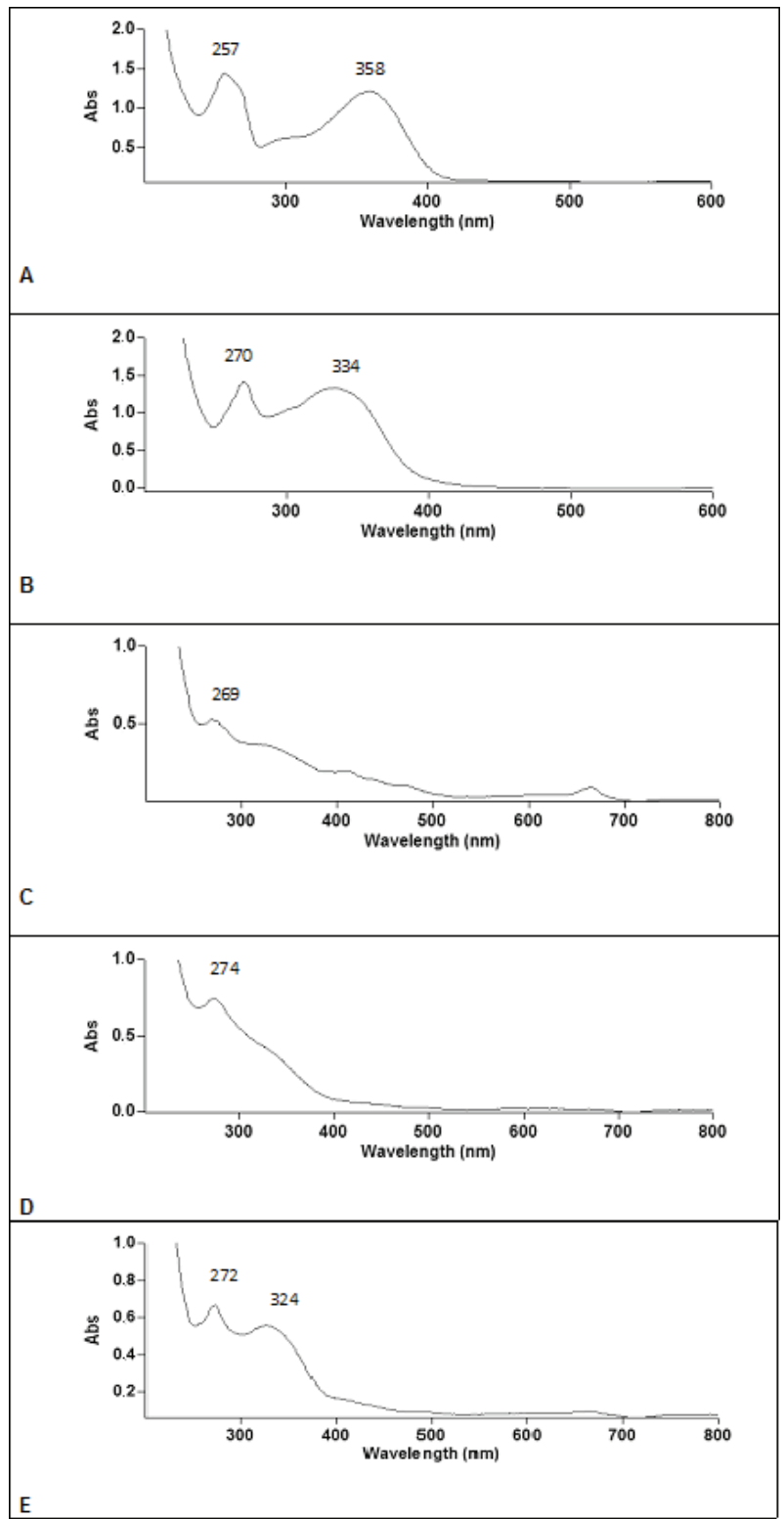

Figure 2. Absorption spectra of reference substances, vegetable raw materials and tablet. A. rutin $0.02 \mathrm{mg} / \mathrm{mL} ; \mathrm{B}$. vitexin $0.02 \mathrm{mg} /$ $\mathrm{mL}$; C. Passiflora powder $0.8 \mathrm{mg} / \mathrm{mL}$; D. Passiflora dried extract $0.5 \mathrm{mg} / \mathrm{mL}$; E. tablet $0.8 \mathrm{mg} / \mathrm{mL}$. 


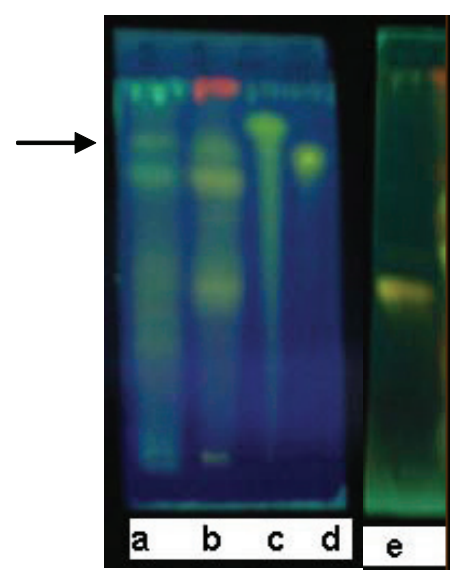

Figure 3. Thin layer chromatography of raw materials and reference substances. a) Passiflora dried extract; b) Passiflora powder; c) vitexin; d) isovitexin, e) rutin. Mobile phase: ethyl acetate:anhydrous formic acid:glacial acetic acid:water (100:11:11:26). Visualization: NP/365 nm.

\section{Quantitative analysis}

The moisture content of raw materials (powder $=5.15 \%$ and dried extract $=5.7 \%$ ) and average weight values for herbal products showed that samples were in accordance with these parameters. The total flavonoids found comprised $2 \%$ of capsule A (containing powder), $0.97 \%$ of capsule B (containing dried extract) and $5.5 \%$ of the tablet.

\section{Validation of spectrophotometry method}

The results of the validation of the spectrophotometric method for quantification of total flavonoids in the capsules are shown in Table 1. The method was found to be selective, linear, precise, accurate and robust for the analysis of the total flavonoids content of Passiflora sp. under the experimental conditions used.

Table 1. Results of the validation of spectrophotometric method to quantify total flavonoids.

\begin{tabular}{|c|c|c|}
\hline $\begin{array}{l}\text { Validation } \\
\text { parameter }\end{array}$ & Capsule A & Capsule B \\
\hline Selectivity & absence of interference & absence of interference \\
\hline Linearity & $\begin{array}{c}y=26.09 x+0.014 \\
r=0.998\end{array}$ & $\begin{array}{c}y=26.09 x+0.014 \\
r=0.998\end{array}$ \\
\hline Range & 2 to $12 \mu \mathrm{g} / \mathrm{mL}$ & 2 to $12 \mu \mathrm{g} / \mathrm{mL}$ \\
\hline Accuracy & $\begin{array}{c}\text { recovery test: } 98.61 \text { to } \\
101.81 \%\end{array}$ & $\begin{array}{c}\text { recovery test: } 98.79 \text { to } \\
101.95 \%\end{array}$ \\
\hline Repeatability & RSD $1.85 \%$ & RSD $1.7 \%$ \\
\hline $\begin{array}{l}\text { Intermediate } \\
\text { precision }\end{array}$ & RSD $1.81 \%$ & RSD $1.91 \%$ \\
\hline Robustness & $\begin{array}{c}\text { wavelength: RSD } 4.07 \% \\
\text { equipment: RSD } 2.33 \% \\
\text { manufacturer of the } \\
\text { glacial acetic acid: RSD } \\
1.59 \%\end{array}$ & $\begin{array}{l}\text { wavelength: RSD } 2.42 \% \\
\text { equipment: RSD } 2.95 \% \\
\text { manufacturer of the } \\
\text { glacial acetic acid: RSD } \\
1.92 \%\end{array}$ \\
\hline
\end{tabular}

During the validation study neither the stability of the solution nor the reaction time for formation of the flavonoid-reactive complex was investigated, since the proposed conditions of the pharmacopeic method did not change.

The method was not validated for tablets because it was not possible to identify the matrix (excipients) used by the manufacturer and this could interfere with the analysis, although it is believed that in the process of extraction and reaction with boric and oxalic acid, which is specific for flavonols, such interference was minimal for the tablet in this study. To this end, the use of HPLC would be recommended.

\section{Validation of dissolution method}

The method was found to be precise in terms of repeatability for the quantification of flavonoids at $401 \mathrm{~nm}$, with aliquots being removed at $30 \mathrm{~min}$ and with an RSD $<5 \%$ (1.06\% for capsules A and $2.16 \%$ for capsules B).

\section{Dissolution tests}

The results of dissolution tests of the samples are presented as percentage of drug dissolved during the preset collection time. As observed, the dissolution of the capsules showed that the average percentages of total flavonoids dissolved (Q) were $87 \pm 1.56 \%$ for those produced with dried extract and $75 \pm 0.794 \%$ for those containing the powder of Passiflora, after the first $10 \mathrm{~min}$ of the test, and this remained practically constant over the next $20 \mathrm{~min}$ (Figure 4). It is interesting to note that although the capsule containing powder of Passiflora employed in this study presented a higher flavonoids content $(2 \%)$, the dissolution of the capsules produced with dried extract (flavonoid content: $0.97 \%$ ) was $12 \%$ higher in the final $30 \mathrm{~min}$. This demonstrates the need for standardization of vegetable raw materials used in the production of herbal products and may be an advantage of the use of dried extracts in relation to powder.

Although there is no pharmacopoeia specification for the dissolution of this herbal product, the acceptance criterion used in this study was at least $75 \%$ of total flavonoids dissolved after $30 \mathrm{~min}$ of testing. On the basis of the results obtained the capsules meet such a specification.

It is important to point out that quick initial release of a drug from its matrix system may be undesirable therapeutically (Jackson et al., 2000). It is necessary to evaluate the release model presented in Figure 4 , in which around 40 to $50 \%$ of the active principle (presented in powder and dried extract, respectively) was released from the formulation in the first 5 min of the test, and further evaluation through studies of bioequivalence 
is necessary to determine whether the organism is able to absorb all of the active principle readily released at the beginning of the dissolution process, without affecting its ability to maintain ideal plasma concentrations for the therapeutic performance of products.

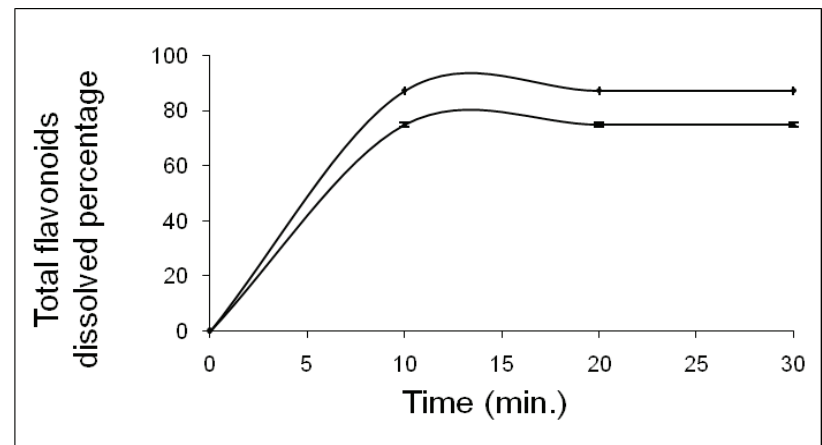

Figure 4. Dissolution profile of capsules containing powder of Passiflora sp (400 mg) or dried extract $(250 \mathrm{mg})$ after $30 \mathrm{~min}$, using paddles, at $50 \mathrm{rpm}$, in $500 \mathrm{~mL}$ of $0.1 \mathrm{M} \mathrm{HCl} \mathrm{pH} 1.2$, with detection at $401 \mathrm{~nm}(\mathrm{n}=6)$. Rhombus: dried extract; square: powder.

Taglioli et al. (2001) demonstrated 50\% dissolution for capsules containing powder of Passiflora sp. and close to $100 \%$ dissolution for capsules containing freeze-dried extract and a standardized extract (Passiflo2$\mathrm{LMF}^{\mathrm{R}}$ ) after about 10 min of test with a paddle apparatus, at a stirring speed of $50 \mathrm{rpm}$, and using water as the dissolution medium at $37 \pm 0.5^{\circ} \mathrm{C}$, with spectrophotometric detection at $340 \mathrm{~nm}$.

The dissolution tests carried out with tablets made from dried extract of $P$. incarnata gave a $Q$ value of $76 \%$. It can be seen that for the capsule and tablet made from dried extract, although they were prepared from different species of Passiflora, the release of flavonoids was $11 \%$ higher for the capsule. The total flavonoids contents were also very different $(0.97 \%$ for capsule compared to $5.5 \%$ for tablet). The differences in the dissolution of these herbal products may have resulted from pharmacotechnical problems such as interaction with excipients in the formulation of tablets, compression force employed in their manufacture, moisture, particle size and various extraction techniques used to obtain the dried extracts (Westerhoff et al., 2002; Calixto, 2000), although none of these factors was investigated in this study.

Finally, it should be emphasized that one of the greatest challenges facing the market for herbal products is the standardization of vegetable raw materials (Capasso et al., 2000; Ong 2004; Liu \& Wang, 2008; Alvarenga et al., 2009; Bueno et al., 2009; Valente et al., 2009). New technologies to modernize the preparation of traditional herbs as part of pharmaceutical products are being evaluated with the ultimate goal of maximizing the opportunities and overcoming the challenges inherent to herbal medicines (Vasconcelos et al., 2005; Yadav \&
Dixit, 2008).

Considering that herbal products represent a market niche and carry the potential to diversify and innovate in the pharmaceutical industry, both in terms of developing new medicines and in improving the quality of those currently available, the implementation of new technologies and processes may contribute to ensuring the efficacy and safety of these products (Alves, 2005). In this context, dissolution studies of herbal medicines may contribute to the process of innovation in the pharmaceutical industry.

\section{Conclusion}

The results obtained allow us to suggest the use of the methods employed in this study in the quality control (analysis of content and dissolution tests) of Passiflora capsules, since the methods were validated by demonstrating selectivity, linearity and range, precision (repeatability and intermediate precision), accuracy and robustness.

For the dissolution test of capsules containing Passiflora sp. (powder or dried extract), the following conditions were validated: stirring speed of $50 \mathrm{rpm}$; apparatus 2, paddle; time for quantification of samples of $30 \mathrm{~min}$; dissolution medium $0.1 \mathrm{M} \mathrm{HCl}$; volume of dissolution medium $500 \mathrm{~mL}$; detection at $401 \mathrm{~nm}$ after reaction with oxalic and boric acid.

It was possible to compare the dissolution of capsules containing Passiflora sp. (powder or dried extract) so that those based on dried extract showed a higher percentage of total flavonoids released into the dissolution medium, although the flavonoids content of herbal products (capsule B) was found to be half that of capsules A (containing powder). We also observed that for both capsules of Passiflora, the maximum dissolution was achieved in the first $10 \mathrm{~min}$ of testing.

\section{References}

Alvarenga FCR, Garcia EF, Bastos EMAF, Grandi TSM, Duarte MGR 2009. Avaliação da qualidade de amostras comerciais de folhas e tinturas de guaco. Rev Bras Farmacogn 19: 442-448.

Alves FNR 2005. Desafio para a inovação em fitomedicamentos no contexto da indústria farmacêutica nacional. Rev Fitos 1: 18-29.

Anvisa 2003. Resolução $n^{\circ} 899$ de 29 de maio de 2003. Determina a publicação do "Guia para validação de métodos analíticos e bioanalíticos".

Bateman J, Champman RD, Simpson, D 1998. Possible toxicity of herbal remedies Scott Med J 43: 7-15.

Bempong DK, Houghton PJ 1992. Dissolution and absorption of caffeine from guarana. J Pharm Pharmacol 44: 769771.

British Pharmacopoeia 2007. Pharmacopoeia Commission British, London. 
Bueno PCP, Bastos JK 2009. A validated capillary gas chromatography method for guaco (Mikania glomerata S.) quality control and rastreability: from plant biomass to phytomedicines. Rev Bras Farmacogn 19: 218-223.

Calixto JB 2000. Efficacy, safety, quality control, marketing and regulatory guidelines for herbal medicines (phytotherapeutic agents). Braz J Med Biol Res 33: 179189.

Capasso R, Izzo AA, Pinto L, Bifulco T, Vitobello C, Mascolo N 2000. Phytotherapy and quality of herbal medicines. Fitoterapia 71: 58-64.

Emea (The European Agency for the Evaluation of Medicinal Products) 2003. Points to consider on the Biopharmaceutical Characterisation of Herbal Medicinal Products.

Jackson K, Young D, Pant S 2000. Drug-excipient interaction and their affect on absorption. Pharmacol Sci Technol Tod 3: 336-345.

Kratz JM, Terrazas CB, Motta MJ, Reginatto, FH, Simões CMO 2008. Determinação da composição química e dos perfis de dissolução in vitro de medicamentos à base de Ginkgo biloba disponíveis no mercado brasileiro. Lat Am J Pharm 27: 674-680.

Kressmann S, Biber A, Wonnemann M, Schug B, Blume HH, Muller WEJ 2002. Influence of pharmaceutical quality on the bioavailability of active components from Ginkgo biloba preparations. Pharm Pharmacol 54: 1507-1514.

Liu Y, Wang MW 2008. Botanical drugs: Challenges and opportunities. Life Sci 82: 445449.

Marques MRC 2002. Desenvolvimento e validação de métodos de dissolução para formas farmacêuticas sólidas orais. Rev Analytica 1: 48-51.

Ngo SNT 2007. When do differences in dissolution profiles predict clinical problems? J Clin Pharm Therapeut 32: 111-112.

Ong ES 2004. Extraction methods and chemical standardization of botanicals and herbal preparations. $J$ Chromatogr $B$ 812: 23-33.

Sittichai N, Karabesri S, Suthison E, Tengamnuay P 2007. An approach to developing dissolution standards for turmeric capsules I: basket rotating method. Thai $J$ Pharm Sci 31: 83-90.

Souza J, Freitas ZMF, Storpirtis S 2007. Modelos in vitro para determinação da absorção de fármacos e previsão da relação dissolução/absorção. Braz J Pharm Sci 43: 515527.

Taglioli V, Bilia AR, Ghiara C, Massi G, Mercati V, Vincieri FF 2001. Evaluation of the dissolution behaviour of some commercial herbal drugs and their preparations. Pharmazie 56: 868-870.

Turolla MSR, Nascimento ES 2006. Informações toxicológicas de alguns fitoterápicos utilizados no Brasil. Braz J Pharm Sci 42: 289-306.

United States Pharmacopeia (USP 30) 2007. Rockville: The United States Pharmacopeial Convention.

Valente ROH, Sampaio FC, Souza IS, Higino JS 2009. Estudo toxicológico pré-clínico (agudo) do extrato do Syzygium aromaticum (L) em roedores. Rev Bras Farmacogn 19: 557-560.

Vasconcelos EAF, Medeiros MGF, Raffi FN, Moura TFAL 2005. Influência da temperatura de secagem e da concentração de Aerosil ${ }^{\circledR} 200$ nas características dos extratos secos por aspersão da Schinus terebinthifolius Raddi (Anacardiaceae). Rev Bras Farmacogn 15: 243-249.

Wagner H, Bladt S 2001. Plant drug analysis. A thin layer chromatography atlas. Berlin: Springer-Verlag.

Westerhoff K, Kaunzinger A, Wurgilics M, Dressman J, Shubert MZJ 2002. Biorelevant dissolution testing of St John's wort products. Pharm Pharmacol 54: 1615-1621.

WHO 1996. WHO Expert Committee on Specifications for Pharmaceutical Preparations. Geneva: WHO Technical Report Series 863: 178-184.

Yadav NP, Dixit VK 2008. Recent approaches in herbal drug standardization. Int J Integr Biol 2: 195-203.

Zuanazzi JAS, Montanha JA 2007. Flavonóides. In Simões CMO (org.) Farmacognosia da planta ao medicamento 6. ed. Porto Alegre/Florianópolis: Ed. UFRGS/Ed. UFSC, p. 577-614.

\section{*Correspondence}

Maria Teresa F. Bara

Laboratório de Pesquisa em Produtos Naturais, Faculdade de Farmácia, Universidade Federal de Goiás Caixa postal 131, 74605-220 Goiânia-GO, Brazil mbara@farmacia.ufg.br Tel. +556232096182 